\title{
Meningkatkan Hasil Belajar Dalam Menyusun Teks Deskriptif Berbahasa Inggris Dengan Penerapan Strategi Picture Word Inductive Model Pada Siswa Kelas IX. SMPN 3 Praya Barat Daya Tahun Pelajaran 2016/2017
}

\author{
Abdi Rabbihim \\ Guru Bahasa Inggris SMPN 3 Praya Barat Daya Kab. Lombok Tengah
}

\begin{abstract}
Abstrak. Penelitian ini bertujuan untuk meningkatkan hasil belajar siswa kelas IX. SMPN 3 Praya Barat DayaSemester 2 Tahun Pelajaran 2016/2017 dalam pembelajaran menulis berbahasa Inggris, terutama dalam mendeskripsikan benda, orang atau tempat tertentu melalui strategi pembelajaran Picture Word Inductive Model. Subyek penelitian adalah 26 siswa IX. SMPN 3 Praya Barat Daya semester 2 Tahun Peajaran 2016/2017. Penelitian ini dilaksanakan selama 2 siklus. siswa bekerja dalam kelompok berempat. Pada siklus pertama siswa mendeskripsikan benda tertentu tanpa strategi Picture Word Inductive Model (PWIM), . Pada siklus ke dua, siswa mendeskripsikan tempat tertentu dengan menggunakan strategi PWIM. Pengumpulan data dilaksanakan bersamaan dengan pengamatan selama tindakan, sementara analisis data dilaksanakan bersamaan pada saat refleksi tindakan. Dari hasil belajar siswa menujukkan rata- rata kelas sebesar 68,42, jumlah siswa yang tuntas sebanyak 16 orang dengan persentase ketuntasan sebesar $61,53 \%$ dan pada siklus II persentase ketuntasan sebesar 88,48 terjadi peningkatan sebesar 16,95 poin ,kemudian pada siklus I jumlah siswa yang belum tuntas sebanyak 9 orang dengan persentase sebesar $34,61 \%$ berarti ketuntasan klasikal sebesar $\leq 80$ belum tercapai,pada siklys II persentase siswa yang belum tuntas sebesar $11,5 \%$ terjadi peningkatan sebesar 23,11 poin. Berdasarkan hal tersebut diatas dapat disimpulkan bahwa PWIM terjadi peningkatan yang signifikan terhadap hasil belajar siswa dalam pembelajaran menulis berbahasa Inggris terutama dalam mendiskripsikan benda/orang/tempat tertentu bagi kelas IX. SMPN 3 Praya Barat Daya semester 2 Tahun Ajaran 2016/2017 dengan strategi PWIM, sehingga strategi ini dapat dijadikan sebagai salah satu strategi dalam pembelajaran Bahasa Inggris.
\end{abstract}

Kata kunci: Hasil Belajar, Menulis Berbahasa Inggris, Teks Deskriptif, $\quad$ Picture Word Inductive Model (PWIM)

\section{PENDAHULUAN}

Latar Belakang Masalah

Menulis adalah salah satu ketrampilan bahasa yang harus dipelajari siswa. Dengan menulis, seseorang bisa menyampaikan gagasan, pikiran dan perasaannya kepada orang lain. Salah satu kelebihan menulis dibandingkan dengan berbicara adalah siswa memiliki kesempatan yang lebih banyak untuk merangkai kata-kata guna menyampaikan gagasan, pikiran dan perasaannya kepada orang lain. Selain itu, kesalahan siswa tidak diketahui secara langsung oleh orang lain, sehingga siswa tidak perlu merasa takut.

Namun demikian, menulis tidak hanya sekedar menyusun/merangkai kata- kata, frasa, atau kalimat. Siswa perlu mengikuti aturan bahasa tertentu untuk bisa memproduksi tulisan yang bisa dipahami dan diterima oleh pembaca. Menurut rangkaian kelangsungan belajar bahasa yang diusulkan oleh Hammond, dan kawan-kawan (2003), menulis lebih baik diberikan kepada siswa SMA pada tingkat akhir. Namun ketrampilan menulis secara sederhana bisa diberikan kepada siswa sejak kelas VII.

Tingkat literasi berbahasa Inggris bagi siswa SMP adalah tingkat fungsional. Siswa diharapkan bisa berkomunikasi secara lisan dan tulis untuk menyelesaikan masalah atau memenuhi kebutuhan sehari-hari seperti menulis pesan singkat, kartu ucapan/undangan, pengumuman, dan lainlain.

Meskipun tingkat literasi yang diharapkan dikuasai siswa hanyalah tingkat 
yang sangat sederhana, tetapi tidak mudah bagi siswa kelas IX SMPN 3 Praya Barat Dayasemester 2 Tahun Pelajaran 2016/2017 untuk mempraktikkannya. Sulitnya memperaktikkan literasi dikarenakan beberapa fakator dintaranya pembelajaran bahasa Inggris pada sekolah sebelumnya belum optimal, karena hanya merupakan materi muatan local, ada banyak perbedaan aturan antara bahasa Indonesia dengan bahasa Inggris, seperti tulisan, konjugasi kata kerja, serta susunan frase benda, serta kata ganti orang, penguasaan kosa kata yang sangat minim oleh siswa.

Dari kendala tersebut diatas terbukti bahwa berdasarkan hasil ulangan harian Bahasa Inggris materi teks deskriptif pada siswa kelas IX. SMPN 3 Praya Barat Dayayang berjumlah 26 siswa sebanyak 12 orang 46,15\% yang telah tuntas mencapai KKM yang ditetapkan SMPN 7 Pujut Tahun Pelajaran 2016 / 2017 yaitu 70 pada semester 2 ,dan sebanyak 14 orang yang belum tuntas atau sebesar 53,84 \%. tidak bisa mengungkapkan makna dalam teks tulis fungsional dan esei pendek sangat sederhana berbentuk deskriptif dan prosedur untuk berinteraksi dengan lingkungan terdekat dengan baik.

Hal tersebut ternyata disebabkan oleh penggunaan media yang kurang tepat kemudian metode pembelajaran yang digunakan tidak sesuai dengan materi yang akan diajarkan,sehingga siswa kurang aktif dalam proses pembelajaran.

Permasalahan siswa tersebut, alternatif yang ditawarkan yaitu menerapkan strategi Power Word Inductive Model guna membantu siswa dalam menemukan sebanyak mungkin kosa kata untuk kemudian disusun menjadi frase, kalimat, dan teks pendek sangat sederhana yang berbentuk dekriptif untuk berinteraksi dengan lingkungan terdekat. Penelitian ini menarik dilakukan karena peneliti berasumsi bahwa siswa akan dapat menuliskan banyak kosa kata secara bersama-sama dengan menggunakan strategi tersebut.

Fokus penelitian ini adalah meningkatnya hasil belajar siswa kelas IX. SMPN 3 Praya Barat Daya pada semester 2
Tahun Pelajaran 2016/2017 dalam pembelajaran menulis berbahasa Inggris. Pembelajaran menulis yang dimaksud di sini adalah mendeskripsikan benda, orang, atau tempat tertentu guna berinteraksi dengan lingkungan di sekitarnya.

Rumusan Masalah.

Dari berbagai gambaran di atas, bisa kita rumuskan permasalahannya sebagai berikut "Bagaimana Meningkatkan hasil belajar Bahasa Inggris Materi Menyusun Teks Deskriptif dengan Penerapan Strategi Picture word Inductive Model (PWIM) pada siswa Kelas IX. SMPN 3 Praya Barat DayaTahun Pelajaran 2016/2017?

\section{Tujuan Penelitian}

Penelitian ini dilaksanakan dengan tujuan untuk Meningkatkan hasil belajar Bahasa Inggris Materi Menyusun Teks Deskriptif dengan Penerapan Strategi Picture word Inductive Model pada siswa Kelas IX. SMPN 3 Praya Barat DayaTahun Pelajaran 2016/2017.

\section{Manfaat Penelitian.}

Penelitian ini diharapkan dapat memberikan beberapa manfaat baik secara teoretis, praktis maupun pedagogis. Secara teoretis, hasil penelitian ini bermanfaat memberikan referensi bagi guru maupun peneliti lain untuk menerapkan atau mengembangkan strategi yang sama/berbeda dalam pembelajaran bahasa Inggris/bahasa lain pada aspek yang sama/lainnya dengan kasus yang sama/berbeda.

Secara praktis, penelitian ini bisa bermanfaat bagi berbagai pihak.

1. Bagi siswa

Siswa terbantu untuk mengungkapkan berbagai hal secara tertulis dengan menggunakan strategi Picture Word Inductive Model. Dengan strategi ini siswa akan lebih mudah untuk Mendeskripsikan benda,tempat atau orang tertentudisekitar mereka.

2. Bagi guru:

Guru peneliti/lain bisa menerapkan metode yang sama guna meningkatkan pembelajaran pada aspek yang sama/lainnya, dengan permasalahan yang sama/berbeda.

3. Bagi Sekolah

Peningkatan hasil belajar siswa dalam bahasa Inggris akan ikut menaikkan prestasi 
sekolah, mengingat pelajaran bahsa Inggris termasuk salah satu pelajaran yang diujikan secara nasional

\section{LANDASAN TEORI DAN KAJIAN PUSTAKA}

Kajian Teoretis.

Sesuai dengan judul, pokok permasalahan yang dihadapi siswa adalah kurangnya hasil belajar siswa dalam pembelajaran menulis berbahasa Inggris. Untuk itu, kajian teori akan difokuskan pada segala sesuatu yang berhubungan dengan pembelajaran menulis berbahasa Inggris, seperti pengertian/kaidah bahasa Inggris, menulis berbahasa Inggris, pembelajaran menulis berbahasa Inggris, teks deskriptif, dan Picture Word Inductive Model.

\section{Bahasa Inggris.}

Bahasa Inggris adalah bahasa yang digunakan oleh orang-orang di negara Inggris atau negara-negara jajahannya (Wikipedia). Bahasa Inggris merupakan bahasa asing pertama di Indonesia yang dianggap penting untuk tujuan penyerapan dan pengembangan ilmu pengetahuan, teknologi, dan seni budaya, dan pembinaan hubungan dengan bangsa-bangsa lain. Mata pelajaran bahasa Inggris merupakan mata pelajaran wajib di sekolah lanjutan tingkat pertama. (KTSP bahasa Inggris SLTP 2004). Seorang siswa belum bisa dikatakan menguasai bahasa Inggris kalau dia belum dapat menggunakannya untuk berkomunikasi, meskipun dia mendapat nilai yang bagus pada penguasaan kosa kata dan tata bahasa. (Pedoman khusus pengembangan silabus dan sistem penilaian bahasa Inggris Kurikulum 2004).

\section{Menulis Berbahasa Inggris.}

Sesuai dengan Standar Isi Bahasa Inggris SMP, Standar Kompetensi menulis berbahasa Inggris kelas VII adalah 1) mengungkapkan makna dalam teks fungsional pendek sangat sederhana untuk berinteraksi dengan lingkungan terdekat dan 2) mengungkapkan makna dalam teks tulis fungsional dan esei pendek sederhana yang berbentuk deskriptif dan prosedur.

Sedangkan Kompetensi Dasar menulis berbahasa Inggris bagi kelas IX.E SMPN 3 Praya Barat Daya pada semester 2 adalah 1) mengungkapkan makna dalam gagasan dalam teks tulis fungsional pendek sangat sederhana dengan menggunakan ragam bahasa tulis secara akurat, lancar dan berterima untuk berinteraksi dengan lingkungan sekitar, 2) mengungkapkan langkah retorika dalam teks tulis fungsional pendek sangat sederhana dengan menggunakan ragam bahasa tulis secara akurat, lancar dan berterima untuk berinteraksi dengan lingkungan sekitar, 3) mengungkapkan makna dalam teks tulis fungsional pendek sederhana dengan menggunakan ragam bahasa tulis secara akurat, lancar dan berterima untuk berinteraksi dengan lingkungan sekitar, serta 4) Mengungkapkan makna dan langkah retorika dalam esei pendek sangat sederhana dengan menggunakan ragam bahasa tulis secara akurat, lancar dan berterima untuk berinteraksi dengan lingkungan terdekat dalam teks berbentuk deskriptif dan prosedur.

$$
\text { Sesuai dengan kontinum }
$$

pembelajaran bahasa seperti yang diajukan oleh Hammond, dan kawan-kawan (2012:5), pembelajaran dimulai dari bahasa yang "paling" lisan hingga yang "paling" tulis. Maka pembelajaran bahasa Inggris di kelas IX sebetulnya masih ditekankan pada bahasa lisan, yaitu mendengarkan dan berbicara. Selain itu, bahasa pada dasarnya adalah lisan (Helena, dkk. 2014) Mereka menambahkan bahwa bahasa lisan adalah bahasa interaksi face-to-face, yang terutama untuk membicarakan 'aku dan kamu'. Namun demikian, tentu saja siswa tidak secara tibatiba diberikan pembelajaran menulis apabila siswa telah duduk di sekolah lanjutan atas. Siswa harus diajarkan bagaimana cara menulis dalam bahasa Inggris dengan benar sejak mereka masih belajar di kelas awal SMPN dengan sangat sederhana. Untuk lebih jelasnya perhatikan diagram kontinum dalam bahasa berikut:

\section{Gambar 1.}

Lisan

Tulis 
Diagram Bahasa Lisan dan Tulis (Hammond et al., 2012:5)

Diagram tersebut menunjukkan bahwa belajar bahasa dimulai dari mempelajari bahasa lisan menuju bahasa tulis. Menulis dalam bahasa Inggris tidak sekedar merangkai kata-kata/frasa atau kalimat bahasa Inggris. Diperlukan beberapa seni dan strategi agar siswa bisa mengungkapkan makna dalam teks tulis fungsional dan esei pendek sederhana yang berbentuk deskriptif dan prosedur.

Secara teori menulis termasuk ketrampilan yang lebih sulit dilakukan siswa dari pada ketrampilan berbicara. Beberapa fitur bahasa tulis seperti penggunaan huruf, tanda baca dan susunan kalimat yang benar sedikit menyulitkan siswa, apalagi bahasa Inggris memiliki perbedaan aturan penulisan dengan bahasa Indonesia. Siswa diharapkan bisa menulis dengan huruf, tanda baca, dan susunan kalimat yang benar agar pembaca bisa memahami tulisan tanpa harus bertanya kepada penulisnya. Selain itu, tidak banyak orang tua siswa yang mengajarkan menulis pada anaknya di rumah, apalagi dalam bahasa Inggris. Apabila anak bisa belajar berbicara di dalam lingkungan keluarganya, tidak demikian dengan belajar menulis. Menulis dipelajari dengan lebih formal di sekolah, dengan berbagai aturan mainnya.

\section{Pembelajaran Menulis Berbahasa Inggris .}

Pembelajaran menulis berbahasa Inggris pada tingkat sekolah lanjutan pertama semester 2 diberikan berdasarkan Standar Kompetensi dan Kompetensi Dasar seperti yang telah diuraikan pada bagian 2.1.2 di atas. Pembelajaran menulis dalam pelajaran bahasa Inggris diberikan dalam 4 tahap, yaitu building knowledge of the field (BKOF), modeling of the text (MOT), joint construction of the text (JCOT), dan independent construction of the text (ICOT).

Pada tahap BKOF, siswa diajak mengeksplorasi pengetahuannya tentang segala sesuatu yang berhubungan dengan topik. Kemudian siswa diberikan contoh dalam tahap MOT. Pada tahap JCOT, siswa diberi kesempatan untuk bekerjasama dengan teman guna mengelaborasi apa yang telah dia dapatkan dari guru selama tahap BKOF, sementara pada tahap ICOT siswa diharapkan bisa melakukan kegiatan secara mandiri, masih dalam rangka mengeksplorasi pengetahuannya.

\section{Teks Deskriptif}

Menurut Wikipedia dan kamus Webster, teks deskriptif adalah sebuah teks yang bertujuan memberikan gambaran yang jelas mengenai benda/orang/tempat tertentu. Yang membedakan teks deskriptif dengan teks report (laporan) adalah bahwa teks deskriptif dibuat berdasarkan fakta tentang benda/orang/tempat tertentu secara khusus, sementara teks laporan dibuat secara umum berdasarkan hasil observasi.

\section{Picture Word Inductive Model}

Calhoun (1998) mengembangkan Picture Word Inductive Model (PWIM), menggunakan foto berisi objek yang dikenal siswa untuk memproduksi kata-kata dari anak-anak. Model ini membantu siswa menemukan beberapa kosa kata melalui apa yang mereka baca dan lihat, serta kosakata yang mereka tulis, dan juga menemukan prinsip fonetik dan struktural yang hadir dalam kata-kata.

Tujuan menggunakan PWIM adalah untuk mengembangkan kosakata, konsep tentang kata-kata,kalimat dan struktur paragraf. Kekuatan menggunakan strategi ini adalah bahwa hal itu akan membantu membangun kosakata dan kemampuan menulis. Berikut adalah daftar keuntungan dari penggunaan $P W I M$ diambil dari Calhoun (2013).

- Strategi ini menekankan phonics, tata bahasa, mekanik, dan penggunaan bahasa Inggris standar. 2) Gambar memberikan referensi yang nyata untuk mempelajari kata-kata baru, frasa, dan kalimat. 3) Karena siswa menggunakan gambar yang terkait dengan materi konten di bawah studi, mereka merasa menjadi bagian dari komunitas kelas dan dapat berhasil belajar dalam kegiatan kelas.

- Grafik kata gambar berfungsi sebagai referensi langsung untuk memungkinkan siswa untuk menambahkan kata-kata dengan kosa kata penglihatan mereka. 5) Siswa dibantu dalam melihat pola dan hubungan dari bahasa Inggris, memungkinkan mereka untuk menerapkan 
belajar kata-kata yang baru ditemui.

- Siswa mendengar dan melihat kata-kata yang dieja dengan benar dan berhasil belajar dalam ejaan dan tulisan yang benar.

- Siswa mendapatkan manfaat dari pemodelan guru dari kata-kata kunci dan konsep yang diperagakan.

Strategi ini dapat digunakan dengan seluruh kelas, kelompok-kelompok kecil, berpasangan, atau individual untuk mengarahkan siswa menjadi bertanya tentang kata-kata dan menambahkan mereka ke kosa kata mereka, menemukan prinsip fonetik dan struktural, dan terlibat dalam kegiatan membaca dan menulis. Sementara beberapa keterampilan dapat diajarkan secara eksplisit, $P W I M$ dirancang untuk memanfaatkan kemampuan siswa untuk berpikir induktif.

Pembelajaran dimulai dengan meminta siswa menuliskan kata benda sebanyak mungkin dari gambar yang mereka lihat. Misalnya focus pada gambar adalah Pangeran William. Siswa bisa menulis beberapa kata benda baik yang terlihat di dalam foto/gambar maupun tidak. Siswa bisa menuliskan 'hat, uniform, hair, face, nose, skin, teeth, smile, body', atau kata benda lain misalnya 'his mom, his brother, dll'. Kemudian siswa diminta menuliskan kata sifat sebanyak mungkin yang menerangkan kata benda yang telah dituliskan sebelumnya, seperti 'handsome, bright, tall, kindhearted, generous, blonde, black', dan lain-lain. Siswa juga bisa menuliskan kata sifat yang muncul di dalam pikiran mereka setelah melihat gambar, meskipun kata sifat tersebut tidak menjelaskan gambar tersebut. Misalnya mereka mengingat ayahnya, Pangeran Charless, atau ibunya, Lady Diana, dan lainlain. Kemudian siswa menuliskan frase benda seperti 'blonde hair, pointed nose, tall body, bright skin', dan lain-lain. Setelah menuliskan frase benda, siswa akan lebih mudah menuliskan kalimat. Mereka bisa menulis ' $\mathrm{He}$ has blode hair', atau 'He is kindhearted like her mother', dan seterusnya sehingga siswa akan terbantu menyusun paragraf, kemudian teks.

\section{METODE PENELITIAN}

Waktu, Tempat, dan Subyek Penelitian
Penelitian ini dilaksanakan selama 3 bulan pada semester 2 Tahun Pelajaran 2016/2017, dimulai pada bulan Januari sampai dengan bulan Maret 2017, dilaksanakan di kelas IX. SMPN 3 Praya Barat Daya Sebagai subyek penelitian adalah 26 siswa kelas IX. SMPN 3 Praya Barat Daya dengan siswa laki- laki sebanyak 12 siswa laki - laki dan perempuan sebanyak 14 siswa. Sebagian besar siswa di kelas ini berasal dari keluarga menengah ke bawah, di mana kondisi keluarga kurang mendukung pembelajaran bahasa Inggris. Tidak banyak orang tua siswa yang memfasilitasi anak mereka dalam mempelajari bahasa Inggris, seperti mengajak menonton film berbahasa Inggris, mengirim anak-anak mereka ke tempat-tempat kursus, apalagi mengajak mereka berlatih menulis berbahasa Inggris.

\section{Sumber data.}

Sebagai sumber data primer adalah 26 siswa kelas IX.E SMPN 7 Pujutn semester 2 Tahun Pelajaran 2016/2017. Hasil pengamatan terhadap kegiatan siswa selama pembelajaran baik yang dikendaki (on task) maupun yang tidak (off task) merupakan data primer yang diambil.

\section{Teknik dan Alat pengumpulan data.}

Penelitian ini difokuskan pada hasil belajar menulis berbahasa Inggris terutama mendiskripsikan benda/orang/tempat tertentu di kelas IX.E SMPN 3 Praya Barat Dayasemester 2 Tahun Pelajaran 2016/2017. Berhubung tehnik pengumpulan data yang digunakan adalah dengan cara menilai hasil belajar siswa, maka alat pengumpul data yang digunakan adalah,hasil tulisan siswa,.

Agar data yang disampaikan dalam penelitian valid, perlu diadakan validasi data. Sesuai dengan tehnik dan alat pengambilan data, validasi data yang digunakan dalam penelitian di sini digunakan Triangulasi data dan penilaian hasil belajar siswa yaitu berupa tulisan yang mendiskripsikan benda/orang/tempat tertentu. Triangulasi merupakan kekuatan dalam penelitian (Woods, 2016). Ada 3 macam triangulasi data menurut Woods (2016), triangulasi metode, triangulasi waktu, dan triangulasi personil. Triangulasi yang dipakai dalam penelitian ini 
adalah triangulasi metode. Triangulasi metode dilakukan dengan cara memberikan metode yang berbeda dalam pembelajaran menulis berbahasa Inggris. Metode yang pertama adalah meminta siswa menulis teks deskriptif berdasarkan gambar yang disediakan guru setelah mendapatkan penjelasan tentang unsur kebahasaan serta hal-hal lain yang diperlukan dalam mendeskripsikan benda, orang, atau tempat tertentu. Pada kesempatan ini siswa bekerja sama berkelompok empat dan individu mendiskripsikan benda tertentu. Metode ke 2 adalah dengan meminta siswa mendeskripsikan orang tertentu dengan menggunakan strategi Picture Word Inductive Model (PWIM) secara berpasangan dan individu. Metode ke 3 adalah meminta siswa mendeskripsikan tempat tertentu secara berpasangan dan individu tanpa menggunakan strategi Picture Word Inductive Model (PWIM). Penilaian hasil belajar siswa dilakukan dengan membandingkan hasil tulisan dengan Kriteria Ketuntasan Minimal belajar bahasa Inggris di kelas IX.E SMPN 7 Pujut.

\section{Analisis data.}

Analisis data dalam penelitian tindakan adalah refleksi tindakan yang telah dilaksanakan. Dari refleksi ini akan diperoleh gambaran apakah tindakan telah menunjukkan adanya keberhasilan sesuai dengan yang diharapkan pada perencanaan awal. Apabila telah mencapai target keberhasilan, maka tindakan boleh dihentikan.

\section{Prosedur penelitian.}

Penelitian ini merupakan penelitian tindakan kelas atau lebih sering dikenal dengan classroom action research untuk meningkatkan hasil belajar siswa kelas IX SMPN 3 Praya Barat Dayasemester 2 (dua) Tahun Pelajaran 2016/2017 dalam pembelajaran menulis berbahasa Inggris guna mengungkapkan berbagai hal yang berhubungan dengan lingkungan terdekat mereka, lebih khususnya adalah mendeskripsikan benda/orang/tempat tertentu.

Penelitian ini dilaksanakan dalam dua siklus dengan metode yang berbeda seperti yang telah diuraikan sebelumnya. Setiap siklus ditempuh dengan empat langkah atau tahap yaitu perencanaan (planning), penerapan tindakan (acting), pengamatan (observing), dan refleksi (reflecting).

HASIL PENELITIAN

DAN

\section{PEMBAHASAN}

Deskripsi Kondisi Awal.

Sebelum diadakan tindakan, 12 atau 48\% dari 26 siswa kelas IX. SMPN 3 Praya Barat Dayasemester 2 Tahun Pelajaran 2016/2017 bisa mendeskripsikan benda/orang/tempat tertentu dan itu hanya berupa frase.

Penjelasan Hasil Pelaksanaan Tindakan:

Tindakan dalam penelitian ini dilaksanakan sebanyak 2 siklus, dan masingmasing siklus terdiri dari 4 tahap. Tindakan dilakukan dengan metode yang berbeda. Hal ini dimaksudkan untuk mengetahui sejauh mana penggunaan strategi Picture Word Inductive Model bisa meningkatkan hasil belajar siswa kelas IX. SMPN 3 Praya Barat Dayapada semester 2 Tahun Pelajaran 2016/2017 dalam pembelajaran menulis berbahasa Inggris. Seperti telah disampaikan sebelumnya, tindakan siklus pertama, siswa mendiskripsikan benda tertentu berkelompok 4 kemudian individu tanpa dengan menggunakan strategi PWIM (Picture Word Inductive Model). . Sementara pada tindakan ke tiga, siswa mendiskripsikan gambar tempat tertentu berkelompok 4 dengan prosedur seperti dalam strategi PWIM (Picture Word Inductive Model).

Pada bagian ini tidak lagi dibahas mengenai Perencanaan Tindakan, namun hanya dibahas hasil Pelaksanaan, Pengamatan dan Refleksi dari masing- masing siklus. Berikut penjelasannya.

Siklus I yang dilaksanakan pada tanggal 21 februari 2017 dengan catatan hasil sebagai berikut ,Hasil belajar siswa menujukkan rata- rata kelas sebesar 68,42 ,jumlah siswa yang tuntas sebanyak 16 orang dengan persentase ketuntasan sebesar $61,53 \%$ dan siswa yang belum tuntas sebanyak 9 orang dengan persentase sebesar $34,61 \%$ berarti ketuntasan klasikal sebesar $\leq$ 80 belum tercapai,jadi penelitian akan di lanjutkan lagi pada siklus beikutnya.

Kemudian siklus II dilaksanakan 
pada tanggal 7 Maret 2017 peneliti mendapatkan data hasil belajar siswa dari soal Formatif sebagai berikut . Hasil belajar siswa pada siklus II menunjukkan peningkatan yang cukup signifikan dimana rata - rata kelas mencapai 80,34, dan jumlah siswa yang tuntas sebanyak 23 orang dengan porsentase ketuntasan sebesar 88,48 \% Kemudian jumlah siswa yang tidak tuntas sebanyak 3 orang atau persentase ketuntasan sebesar 11,5 $\%$ dengan demikian ketuntasan klasikal telah tercapai sebesar $\leq 80 \%$.

Dilihat dari rata - rata kelas terjadi peningkatan sebesar 11,92 pada siklus I rata - rata sebesar 64,42 dan rata rata pada siklus II sebesar 80,34 kemudian persentase ketuntasan pada siklus I sebesar68,42 dan pada siklus II sebesar ini terjadi peningkatan sebesar 88,48 sehingga penelitian ini dihentikan pada siklus II karena ketuntasan klasikal telah tercapai.

\section{PENUTUP}

Berdasarkan pengamatan selama tindakan, ada perubahan signifikan hasil belajar siswa kelas IX. SMPN 3 Praya Barat Daya semester 2 Tahun Pelajaran 2016/2017dalam mendiskripsikan benda/orang/tempat tertentu ketika digunakan Picture Word Inductive Model.

Sebelum diadakan tindakan, hanya 12 siswa bisa mendiskripsikan benda/orang/tempat tertentu berbahasa Inggris. Ketika diadakan wawancara, diperoleh jawaban penyebab siswa kurang bisa mengikuti pembelajaran menulis berbahasa Inggris, diantaranya adalah a. siswa tidak memiliki bahan apa yang harus dituliskan, dan b. siswa bosan dengan tehnik yang terkesan monoton.

Hasil belajar siswa menujukkan rata- rata kelas sebesar 68,42, jumlah siswa yang tuntas sebanyak 16 orang dengan persentase ketuntasan sebesar $61,53 \%$ dan siswa yang belum tuntas sebanyak 9 orang dengan persentase sebesar $34,61 \%$ berarti ketuntasan klasikal sebesar $\leq 80$ belum tercapai,jadi penelitian akan di lanjutkan lagi pada siklus beikutnya.

Kemudian siklus II dilaksanakan pada tanggal 7 Maret 2017 peneliti mendapatkan data hasil belajar siswa dari soal
Formatif sebagai berikut : Hasil belajar siswa pada siklus II menunjukkan peningkatan yang cukup signifikan dimana rata - rata kelas mencapai 80,34, dan jumlah siswa yang tuntas sebanyak 23 orang dengan porsentase ketuntasan sebesar 88,48 \% Kemudian jumlah siswa yang tidak tuntas sebanyak 3 orang atau persentase ketuntasan sebesar 11,5 $\%$ dengan demikian ketuntasan klasikal telah tercapai sebesar $\leq 80 \%$

Dilihat dari rata - rata kelas terjadi peningkatan sebesar 11,92 pada siklus I rata - rata sebesar 64,42 dan rata rata pada siklus II sebesar 80,34 kemudian persentase ketuntasan pada siklus I sebesar68,42 dan pada siklus II sebesar ini terjadi peningkatan sebesar 88,48 sehingga penelitian ini dihentikan pada siklus II karena ketuntasan klasikal telah tercapai.

DAFTAR PUSTAKA

Carr, W. \& Kemmis, S. (2006) Becoming Critical: education, knowledge and action research. Lewes: Falmer.

Cohen, L ; Manion, L \& Morrison, K (2008) Research Methods in Education (5th edition). London,:Routledge Falmer.

Denzin \& Y. Lincoln (Eds.) Handbook of Qualitative Research 2nd Development. In M. Huberman, \& J. M. Backus (Eds.), Advances in Development. London: Heinemann.

Dep.dik.nas, (2013) Kurikulum 2013, Standar Kompetensi Mata Pelajaran Bahasa Inggris Sekolah Menengah Pertama dan Madrasah Tsanawiyah. Jakarta.

(2011) Action Research for Educational Change.

Buckingham: Open University Press.

Fischer, J. (2001). Action Research Rationale and Planning: Developing a Framework for Teacher Inquiry. In G. Burnaford, J. Fischer \& D.

Education, 15 (1): 59-64.

Kemmis, S. \& McTaggart, R. (2012) The 
Jurnal dan Pendidikan Ilmu Sosial

http://ejournal.mandalanursa.org/index.php/JISIP/index
Vol. 4. No. 1 Januari 2020

p-ISSN: 2598-9944 e-ISSN: 2656-6753

Action Research Planner.

Victoria, Deakin University

Press.

Koshy, V. (2005) Action research for improving practice. A practical guide.London: Paul Chapman Publishing.

Woods, P. 2006. Qualitative Research. University of Plymouth. 